\title{
KONSEP KEPEMILIKAN EKONOMI ISLAM MATERI FIQH KELAS XII (IMPLIKASINYA TERHADAP PENDIDIKAN AGAMA ISLAM UNTUK MENANGGULANGI PENGANGGURAN)
}

\author{
Rahmat \\ Dosen PAI Institut Pesantren KH Abdul Chalim Pacet Mojokerto \\ Email: rahmatpaikhac@gmail.com \\ Muhammad Husnur Rofiq \\ Dosen PAI Institut Pesantren KH Abdul Chalim Pacet Mojokerto \\ Email: umasoviq@gmail.com
}

\begin{abstract}
Abstrak
Manusia secara fitrah cenderung bersenang-senang, dan cinta akan banyaknya istri, anak dan harta. Hal ini telah Allah Swt gambarkan dalam firman-Nya Surat Ali Imran ayat 14; "Dijadikan terasa indah dalam pandangan manusia cinta terbadap apa yang diinginkan, berupa perempuan-perempuan, anak-anak, harta benda yang bertumpuk dalam bentuk emas dan perak, kuda piliban, hewan ternak dan sawab ladang. Itulah kesenangan bidup di dunia, dan disisi Allah lah tempat kembali yang baik". Ayat tersebut, dapat dimaknai sebagai penjelasan bahwa kecenderungan terhadap kesenangan memang fitrahnya manusia. Oleh sebab itu, sudah pasti ia terdorong untuk berusaha menjadi kaya dan lain sebagainya. Sedangkan melarang dorongan fitrah tersebut merupakan pelanggaran baik dalam kaca mata Islam maupun hukum yang berlaku. Adapun Islam telah mengatur bagaimana cara manusia memperoleh kekayaan sesuai tingkat kebutuhan dan kemampuan serta bagaimana cara ia
\end{abstract}

Nazhruna: Jurnal Pendidikan Islam

Vol. 1 No 2 Agustus 2018. Issn: 2614-8013. Hal. 241-275 
menggunakannya sehingga, kekayaannya kelak akan berguna bagi agama, dunia dan akhiratnya.

Kata kunci: Konsep kepemilikan, Pendidikan Agama Islam, dan Pengangguran

\section{Abstract}

Humans naturally tend to have fun, and love for many wives, children and possessions. This has been described by Allah Almighty in His Word, Surah Al Imran verse 14; "It is made to feel beautiful in the human view of love for what is desired, in the form of women, children, accumulated property in the form of gold and silver, selected horses, farm animals and fields. That is the pleasure of living in the world, and beside Allah is a good place to return ". This verse, can be interpreted as an explanation that the tendency towards pleasure is indeed the nature of man. Therefore, it is certain that he is motivated to try to be rich and so forth. Whereas banning this natural urge is a violation both in the eyes of Islam and applicable law. As for Islam, it has regulated how humans obtain wealth according to the level of needs and abilities and how they use it so that their wealth will be useful for religion, the world.

Keyword: ownership concept, Islamic education, and unemployment

\section{Pendahuluan}

Dalam kitabnya, Tamlikul Amwal Dr. Abdurrahman Jalil menjelaskan konsep kepemilikan sebagaimana berikut:

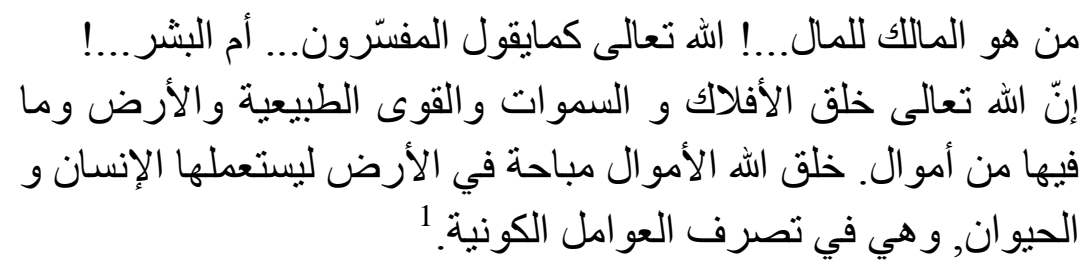

Dijelaskan di atas, pemilik yang hakiki terhadap harta adalah Allah Swt. Allah lah pencipta langit besarta isinya dan

1 Abdurrahman al-Jalil, Tamliku al-Amwal wa Tadkhulu al-Daulah fi alIslam, (Riyad: Dar al-Ulum, 1988), hlm. 19. 
bumi berserta isinya. Dan Allah menciptakan kesemua itu agar dapat dimanfaatkan dengan sebaik-baiknya oleh makhluknya terutama manusia dan hewan.

Ideologi Kapitalisme pada tingkat implementasi melahirkan politik ekonomi Kapitalisme. Ideologi Sosialisme Marxisme juga melahirkan politik ekonomi Sosialisme. Demikian juga agama Islam. Sebab Islam merupakan ideologi. Ideologi Islam juga melahirkan politik ekonomi Islam.

Ideologi Kapitalisme memiliki instrumen penting dalam politik ekonominya berupa penjajahan kepada negara atau bangsa lain. Penjajahan ini dilakukan guna mempertahankan ideologi Kapitalisme. Dalam buku Politik Ekonomi Islam ${ }^{2}$ tertulis sebelum perang dunia kedua bentuk penjajahannnya berupa penguasaan teritorial dan militer. Setelah perang dunia kedua penjajahan berubah bentuk menyusul tidak efektifnya penjajahan model itu.

Penjajahan gaya baru berupa pemberiaan utang melalui IMF, IDB, dan sejenisnya, lembaga-lembaga perdagangan internasional seperti WTO, PBB, penanaman modal asing, pembentukan pasar bebas. Dan baru itu. Sebagai contoh Indonesia. Indonesia kini mengalami krisis ekonomi yang mengerikan. Salah satu penyebab adalah Dept Traps yang tak mungkin dilunasi dalam jangka waktu seratus tahun. Kini Indonesia dalam kekuasaan IMF. Apakah IMF datang ke Indonesia untuk membantu memulihkan ekonomi Islam? Alihalih membantu, datangnya IMF justru menambah panjangnya krisis ekonomi, juga berdampak dijualnya aset-aset negara yang sangat strategis untuk memenuhi hajat hidup orang banyak keapda negara Kapitalis maju dengan harga sangat murah. Dinaikannya harga BBM, tarif telpon dan listrik yang secara

2 Ibnu Sholah, Politik Ekonomi Islam, (Bangil: Al-Izzah, 2001), hlm. v. Buku terjemah dari karya Abdurrahman Al-Maliki, as-Syiyasatu al-Iqtishadiyatu alMutsla. 
langsung berdampak memicu kenaikan barang-barang lain. Padahal kenaikan itu tidak disertai dengan kenaikan daya beli masyarakat. Sebenarnya yang terjadi, program-program restrukturisasi ekonomi yang didiktekan kepada Indonesia hanyalah untuk memuluskan negara-negara Kapitalis menguasai Indonesia, baik ekonomi maupun politik.

Pemaparan di atas merupakan segelintir contoh bagaimana negara Kapitalis Barat mengaplikasikan konsep penjajahan kepada negara-negara berkembang guna melanggengkan ideologi Kapitalisnya. Hal serupa juga sebenarnya dapat terjadi pada politik ekonomi Sosialisme.

Begitu buruknya kedua politik ekonomi tersebut. Akan tetapi pertanyaannya kenapa umat Islam justru berbondongbondong menganut paham keduanya untuk mengatur negara mereka? Jawabanya sederhana saja, bisa jadi karena umat Islam ketika bukan lagi sebagai institusi negara Islam hingga terjadi berbagai malapetaka yang menimpa mereka. Kaum muslimin tidak lagi memegangi ideologi Islam serta pemikiran-pemikiran cabangnya yang Islami untuk menyelesaikan setiap persoalan hidup. Yang terjadi mayoritas umat ini semakin jauh dari agamanya. Sehingga dalam kondisi itu amat memungkinkan kalau mereka berbondong-bondong menerapkan cara hidup Kapitalisme yang liberal tersebut. Sebab, dari segi materi Kapitalisme berhasil memberi kemajuan teknologi untuk memanjakan kehidupan duniawi yang hidup serba kebebasan. 
1. Konsep Kepemilikan dalam Islam

a. Kepemilikan dalam Sejarah

1) Konsep Kapitalis

Sejarah lahirnya kapitalisme dilandasi oleh semangat keagamaan, ${ }^{3}$ namun sepak terjang kapitalisme malah lari dan melemahkan nilai nilai etis dari ajaran keagamaan itu sendiri.

Pada awalnya, ketika paradigma sekuler masih terbatas pada sekelompok kecil para akademisi, konflik antara model agama (gereja) dan ilmu tidak mempunyai dampak yang signifikan pada ekonomi dan masyarakat. Nilai nilai agama tetap mendominasi, dan mampu mengatasi dampak paradigma sekuler pada mekanisme yang dipakai. Namun seiring dengan perkembangannya secara gradual, nilai nilai sekuler cenderung meluas. ${ }^{4}$

Ada beberapa tokoh liberalisme. Dan John Lock merupakan orang pertama yang menggagas liberalisme dalam hak milik, yang merupakan hak terpenting atas kehidupan dan kebebasan. ${ }^{5}$ Ide liberalisme ini menguat ketika alat tukar menggunakan uang, hak milik menjadi sangat luas dan tidak terbatas, sepanjang tidak merugikan orang lain, asalkan memiliki sejumlah uang yang dapat membeli kepemilikan lain. Menurut Lock kapitalisme adalah pada pandangannya terhadap pekerjaan yang harus diukur dengan nilai tukar komoditas yang ada di masyarakat.

Adam Smith adalah tokoh lain yang mendukung liberalisme, ia mengikuti tokoh sebelumnya mengenai pentingnya hak milik pribadi. Pendapat Smith yang yang terkenal tentang pentingnya hak milik adalah the sacred rights of

${ }^{3}$ Moral keagamaan "sitem ekonomi pasar bebas".

4 Umer Chapra, Masa Depan Ilmu Ekonomi : sebuah tinjauan Islam diterjemahkan oleh : Ikhwan Abidin Basri (Jakarta: Gema Insani Press.,2001), hlm. 17.

${ }^{5}$ Syafiq M. Hanafi, Sistem Ekonomi Islam \& Kapitalisme : relevansi ajaran agama Islam dalam aktivitas ekonomi, (Cakrawala, Maret 2007), hlm. 82. 
private property. Secara substansi, Smith sepakat dengan John Lock menganggap bahwa kerja merupakan dasar dari hak milik pribadi, tetapi memandang lebih jauh terhadap kesempurnaan hak milik. ${ }^{6}$

Besarnya pengaruh ide kepemilikan pribadi dengan landasan liberalisme semakin membuat jarak yang jauh antara orang kaya dan miskin. Sistem ini kurang memperhatikan nasib orang miskin dan orang yang tidak beruntung dalam hidupnya. Kapitalisme menempatkan manusia pada posisi yang rancu, dan tidak mampu menempatkan manusia sebagai makhluk individu dalam bingkai sosial. Penekanan yang berlebihan pada maksimalisasi kekayaan dan pemuasan keinginan, serta pengumbaran kepentingan diri sendiri individual. ${ }^{7}$

Menurut kapitalis, kepemilikan diidentikkan dengan hak menguasai suatu hal, padahal kepemilikan bukan terkait dengan hal yang bersifat materi. Kepemilikan juga tidak bisa dilihat dari hasil, sebab terdapat kepemilikan yang terjadi tanpa lewat kerja, misalnya harta warisan. Dengan demikian kepemilikan membutuhkan legalitas hukum. Melalui titik inilah konsep kepemilikan kapitalis dinilai gagal.

2) Konsep Sosialis

Pada akhirnya, hak milik individu ini menarik perhatian Karl Marx dalam mengembangkan idenya dengan lebih menjadikannya sebagai doktrin kebijakan sosioekonomi dan politiknya. Pemikiran Marx membimbingnya untuk mewujudkan kekuasaan sosial sebagai pemerataan. ${ }^{8}$

${ }^{6}$ Adam Smith, Lectures on Jurisprudence, dikutip dari Syafiq M. Hanafi, Sistem Ekonomi Islam \& Kapitalisme... hlm. 83.

${ }^{7}$ Umer Chapra, Masa Depan Ilmu Ekonomi : sebuah tinjauan Islam..... hlm. ix-x. hlm. 226.

${ }^{8}$ Baca, Muhammad Baqir Sadr, Iqtishaduna, (Dar al Kitab al Islamiy, ttl), 
Karl Marx mengungkapkan bahwa manusia dan alam mempunyai hubungan timbal balik yang diwujudkan dalam sebuah pekerjaan. Hubungan yang harmonis tersebut terganggu ketika para kaum buruh terus-terusan menjual pekerjaannya sebagai komoditas kepada para kapitalis dengan upah yang minim. Sistem yang berlaku ketika itu tidak dapat berbuat apa-apa, dan para buruh tidak pernah mempunyai hak milik dari pekerjaannya sendiri. Keadaan yang tidak adil tersebut dianggap sebagai cara berproduksi dan memperoleh kekayaan yang mengeksploitasi manusia.

Permasalahan di ataslah yang memicu Marx dan Marxisme menolak hak milik pribadi yang ditegaskan dalam Manifesto Partai Komunis, dengan ungkapan bahwa teori mendasar Partai Komunis seolah-olah berniat merumuskan penghapusan hak milik.

Jelasnya, dalam perekonomian kepemilikan yang dihapus adalah kepemilikan terhadap harta (kapital) yang merupakan sarana produksi, karena harta merupakan social power dan bukan hak milik individual. Harta/maal merupakan sarana pekerjaan secara kolektif yang memungkinkan seluruh masyarakat dapat bekerja dengan baik dengan pendapatan yang layak. Lembaga milik pribadi merupakan penindasan dan eksploitasi kaum pekerja dengan menghisap tenaga kerja orang lain.

3) Konsep Islam

Dalam kitab Tamlikul Amwal disebutkan konsep Islam dalam kepemilikan sebagaimana berikut:

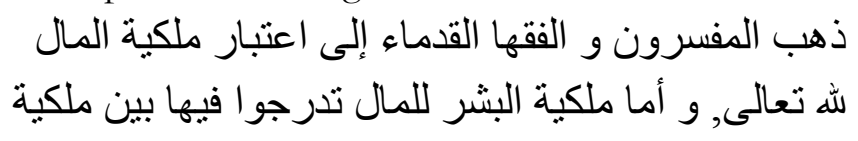

9 Karl Marx and Frederick Engels, The Communist Manifesto, (Harmonsworth : Penguin Books, 1974), hlm. 96. 


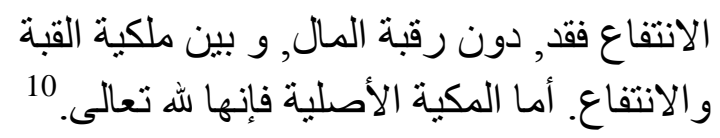

Para Mufassirin dan para ahli fikih berpendapat konsep kepemilikan suatu harta itu milik Allah Swt, adapun kepemilikan manusia terhadap suatu harta itu relatif yakni hanya pada tataran memiliki manfaatnya saja bukan zat harta itu sendiri. Karena pemilik sejati hayalah Allah Swt. Lebih jelasnya mengenai konep kepemilikan ini, penulis menganjurkan untuk membaca keterangan berikut.

a) Al-Qur'an dan Sunnah (Fikih Muamalah)

Milik (dalam bahasa Arab, al-milk\} secara bahasa berarti pemilikan atas sesuatu (almal, atau harta benda) dan kewenangan bertindak secara bebas terhadapnya". ${ }^{11}$ Masalah milik menempati $90 \%$ dalam persoalan hukum dalam masyarakat. ${ }^{12}$

Beberapa ahli Barat menyatakan Islam sebagai agama yang menjaga diri, tetapi toleran membuka diri. Selain itu para ahli tersebut menyatakan Islam adalah agama yang memiliki unsur keagamaan dan memntingkan segi ahkhirat dan segi dunia. Demikian juga hakikatnya pemilik alam semesta beserta isinya hanyalah Allah semata. Manusia hanyalah merupakan wakil Allah dalam rangka memakmurkan dan menyejahterakan bumi. Kepemilikan manusia merupakan derivasi kepemilikan Allah yang hakiki. Untuk itu, setiap langkah dan kebijakan ekonomi diambil oleh manusia untuk memakmurkan

${ }^{10}$ Ibid., Abdurrahman al-Jalil, Tamliku al-Amwal wa Tadkhulu al-Daulah fi al-Islam, ..... hlm. 346.

${ }^{11}$ Musthafa Ahmad al-Zarqa', al-Madkhal al-Fiqh al-'Amm, (Beirut: Daral Fikr, 1968), Jlid I, hlm, 240. 1992), hlm. 82.

${ }^{12}$ Save M. Dagun, Pengantar Filsafat Ekonomi, (Jakarta: PT Rineka Cipta, 
alam semesta tidak boleh bertentangan dengan ketentuan yang digariskan oleh Allah Yang Maha Memiliki. ${ }^{13}$ Allah Swt berfirman yang artinya.

Artinya: kepunyaan Allahlah kerajaan langit dan bumi dan apa yang ada diantara keduanya; Dia menciptakan apa yang dikehendaki-Nya. dan Allah Maha Kuasa atas segala sesuatu. ${ }^{14}$

Konsep kepemilikan dalam Islam diantaranya mengacu pada prinsip Al-Qur'an sebagaimana berikut ini:

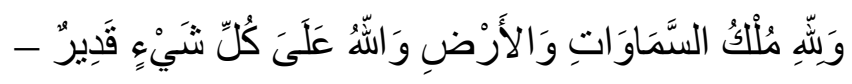

Artinya: kepunyaan Allah-lah segala apa yang ada di langit dan apa yang ada di bumi. (Q.S. Al-Imran: 189).

Dan Allah Swt menegaskan sebagaimana firmanNya berikut ini:

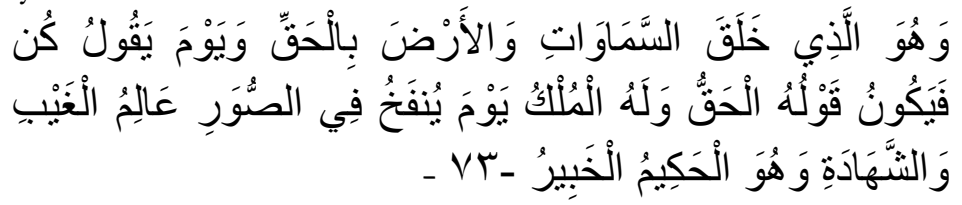

Artinya: dan Dialah yang menciptakan langit dan bumi dengan benar. dan benarlah perkataan-Nya di waktu Dia mengatakan: "Jadilah, lalu terjadilah", dan di tanganNyalah segala kekuasaan di waktu sangkakala ditiup. Dia mengetahui yang ghaib dan yang nampak. dan Dialah yang Maha Bijaksana lagi Maha mengetahui. (Q.S. AlAnam: 73).

13 Ismail Nawawi, Ekonomi Kelembagaan Syariah "Dalam Pusaran Perekonomian Global Sebuab Tuntutan dan Realitas", (Surabaya: Cv. Putra Media Nusantara, 2009), hlm. 21-22.

${ }^{14}$ Lihat, Mardani, Ayat-ayat dan Hadis Ekonomi Syariah (Jakarta: Rajawali Pers, 2011), hlm. 1-202. 
Kedua ayat di atas (Q.S. Al-Imran 189 dan AlAnam 73) mengungkapkan bahwasanya semua yang ada di langit dan dalam bumi merupakan kepunyaan Allah Swt yang tampak maupun yang gaib, dan dengan kemurahan dari-Nya Allah memberikan beberapa hak bagi hamba-Nya. Di sini jelas kepemilikan Allah Swt atas seluruh ciptaannya tidak diragukan lagi bersifat hakiki dan mutlak.

Al-Qur'an telah mengabarkan firman Allah Swt bahwa hanya Allah pemilik langit dan bumi beserta isinya. Karena memang Dia-lah pencipta alam semesta beserta isinya sebagaimana ayat berikut ini:

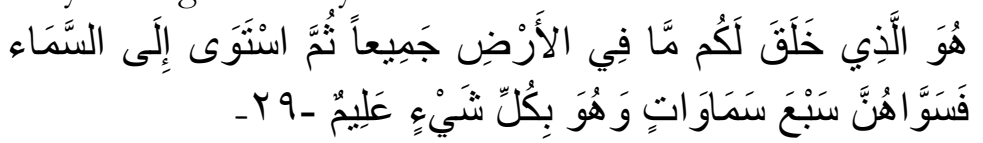

Artinya: Dia-lah Allah, yang menjadikan segala yang ada di bumi untuk kamu ......... (Q.S. Al-Baqarah: 29).

Adapun bumi beserta isinya diciptakan-Nya untuk seluruh makhluk terutama manusia yang oleh Allah Swt manusia, makhluk sempurna itu dilantik sebagai khalifah atau pemimpin di muka bumi sebagaimana firman-Nya berikut ini:

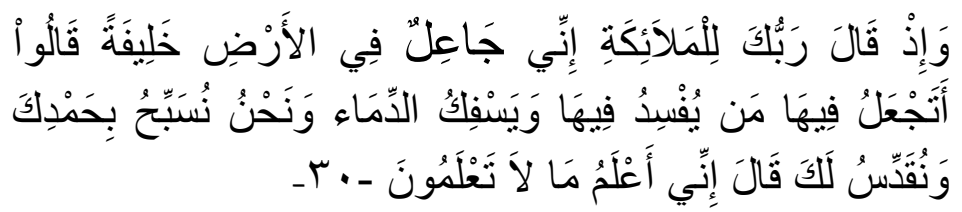

Artinya: ingatlah ketika Tuhanmu berfirman kepada Para Malaikat: "Sesungguhnya aku hendak menjadikan seorang khalifah di muka bumi." ....... (Q.S. Al-Baqarah: 30).

Apabila di atas disebutkan kepemilikan Allah Swt atas segala ciptaan-Nya bersifat mutlak maka sebaliknya 
kepemilikan hamba-Nya masih bersifat nisbi atau relatif. ${ }^{15}$ Oleh karenanya, makhluk Allah seperti manusia harus bekerja keras guna memperoleh haknya. Dengan bekerja keras itu lah si manusia dapat memenuhi hasrat dan mensejahterakan keluarganya. sebagaimana ayat berikut ini:

Berikut Q.S. Al- Jumu'ah ayat 10 yang memerintahkan manusia untuk ikhtiar bekerja keras:

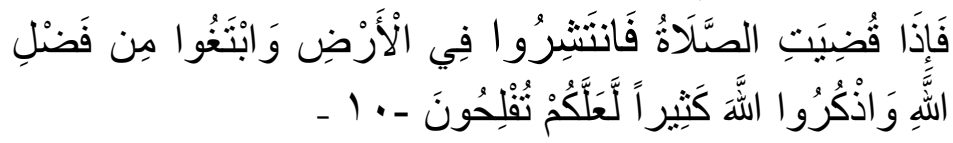

Artinya: .... Maka bertebaranlah kamu di muka bumi; dan carilah karunia Allah.....

Ada beberapa ayat menurut Rifat Syauqi Nawawi ${ }^{16}$ yang menegaskan agar manusia itu hendaknya paham tanggungjawabnya dimuka bumi ini. Manusia harusnya hidup dalam semangat bekerja keras (Q.S. al-Taubah: 105), tidak menyia-nyiakan amanat dari Allah Swt (Q.S. al-Nisa': 58), hidup tidak berlebihan atau boros (Q.S. alFurqan: 67), dan memikirkan masa depan (Q.S. al-Hasyr: 18). Dan sebenarnya masih banyak lagi ayat-ayat yang bersifat sosial.

${ }^{15}$ Dalam hadis yang diriwayatkan oleh Tirmidzi: 2341 dan Darimi: 536, 538, "Dari Abu Barzah Al-Aslami berkata: babwasanya Rasulullah Saw telah bersabda: Pada hari kiamat kelak seorang hamba tidak akan melangkabkan kakinya kecuali akan ditanya tentang empat perkara; tentang umurny untuk apa ia habiskan, tentang ilmunya sejaubmana ia mengamalakannya, tentang hartanya darimana ia mendapatkannya dan untuk apa ia pergunakan, serta tentang semua anggota tububnya apa yang ia perbuat dengannya." Dari hadis ini (umur, ilmu, harta dan tubuh) merupakan kepunyaan Allah Swt yang dititipkan kepada hambanya yang kelak si hamba tersebut akan dimintai pertanggungjawabannya di hadapan Allah Swt. Lihat, Misbah Munir, Ajaran-ajaran Ekonomi Rasululah (Malang: UIN-Malang Press, 2007), hlm. 31-33.

${ }^{16}$ Ri'at Syauqi Nawawi, "Perspektif Al-Qur" an tentang Ekonomi", dalam, Jauhar: Jurnal Pemikiran Islam Kontekstual, (Jakarta: PPS UIN Syarif Hidayatullah, 2000), Vol. 1, No. 1, hlm. 91. 
Hal serupa disabdakan oleh Nabi Muhammad Saw dalam beberapa haditsnya seperti hadits yang diriwayatkan al-Baihaqi:

Nabi Muhammad ditanya: "Pekerjaan apa yang baik wahai Rosulullab?" nabi Mubammad Saw menjawab "apapun yang dikerjakan tangan seorang laki-laki. Setiap perdagangan itu (hendaknya dilakukan dengan) baike". ${ }^{17}$

Hadits di atas mengindikasikan bahwa apapun pekerjaannya, asalkan dilakukan dengan cara yang benar menurut syari'at (tidak ada unsur penipuan dan segala macam tipu daya dalam berbisnis) maka jelas tidak hanya menguntungkan akan tetapi menentramkan pelaku bisnis itu sendiri karena sebagai umat beragama khususnya Islam sebuah perasaan tentram itu pasti berlandaskan perspektif kebenaran.

Dengan demikian, Allah Swt merupakan pemegang otoritas tertinggi atas seluruh ciptaan-Nya dan Dia-lah yang menentukan segala hak yang dapat diperoleh hamba-Nya. Bagi hamba Allah Swt hendaknya menyadari kalau ia harus dapat memahami bahwa Islam memperjuangkan haknya dan mewanti-wanti manusia agar tidak bertindak di luar batasan yang telah Allah gariskan dalam syari'at tersebut.

b. Kepemilikan dan Klasifikasinya dalam Islam ${ }^{18}$

1) Individu

Dalam pembahasan mengenai hak milik individu dalam ekonomi Islam ada dua hal yang diuraikan

${ }^{17}$ Transaksi jual beli yang benar menurut syari'at serta bermanfaat bagi sosial.

18 Bandingkan dengan, konsep Syekh Taqiyuddin, Membangun Sistem Ekonomi Alternatif: Perspektif Islam, ter. Moh. Maghfur Wachid, Surabaya: Penerbit Risalah Gusti, 1996, dalam Muhammad Djakfar, Agama, Etika, dan Ekonomi, Edisi Revisi, (Malang: UIN Press, 2014), hlm. 27-36. 
yaitu terkait dorongan manusia untuk memiliki harta dan keterikatan harta idnividu itu sendiri.

a) Dorongan Manusia untuk Memiliki Harta Islam memandang manusia adalah makhluk yang memiliki dorongan-dorongan dan instinginsting sosial yang merupakan fitrah. Di antara insting itu adalah insting menyukai harta benda yang mendorong manusia melakukan usaha, membangun dan merasa ingin abadi. Pengakuan adanya insting ini banyak sekali diungkapkan dalam Al-Qur'an antara lain adalah firman Allah Swt:

Artinya: 19. dan kamu memakan harta pusaka dengan cara mencampur baurkan (yang halal dan yang bathil), 20. dan kamu mencintai harta benda dengan kecintaan yang berlebihan.

b) Keterikatan Hak Milik Individu

Islam mengikat kemerdekaan seseorang dalam menggunakan hak milik khususnya dengan ikatan-ikatan yang menjamin tidak adanya bahaya terhadap orang lain atau mengganggu kemaslahatan umum. Hak milik menurut Islam menyangkut semua yang dimiliki manusia, meskipun hak milik itu diadakan untuk memperoleh satu kemaslahatan (kepeningan), tetapi ia masih terikat sehingga tidak menimbulkan bahaya (bahaya terhadap diri sendiri maupun orang lain). menimbulkan bahaya adalah penganiayaan, sedangkan penganiayaan itu dilarang oleh nash Al-Qur'an Karim.

Penghormatan terhadap hak milik tampak sebagai berikut: 
(1) Syari'at menganggap harta termasuk lima tujuan yang wajib dijaga dan dipelihara. Lima tujuan ini adalah: agama, jiwa, akal, kehormatan dan harta.

(2) Syari'at melarang orang melanggar ketentuan atas harta ini dengan bentuk apapun dari bentuk pelanggaran. ${ }^{19}$

Jelas dapat diketahui bahwa hak milik individu bukanlah mutlak, tetapi terbatas dengan ikatanikatan untuk menghilangkan marabahaya terhadap orang lain atau terhadap kemaslahatan umum.

2) Umum

Di samping hak milik individu, Islam juga mengkui hak milik kolektif. Yang dimaksud dengan hak milik umum atau kolektif ialah harta yang dikhususkan untuk kepentingan umum atau kepentingan jamaah kaum muslimin. Hal ini adalah kebalikan dari hak milik khusus yang memanfaatkannya hanya untuk individu atau beberapa individu tertentu secara khusus. Hak milik ini biasanya meliputi milik-milik umum yang ada dalam negara, seperti jalan-jalan, aliran-aliran sungai, dan sebagainya.

Negara Islam telah mengakui macam hak milik ini sejak awal sejarahnya dalam berbagai macam bentuk. Secara ringkas adalah dalam dua bentuk berikut ini yang mempunyai urgensi, karena pengaruhnya atas ekonomi negara.

a) Tanah Suaka

Tanah suaka (Ardu-Hima) adalah sebidang tanah yang diurus oleh pemerintah, ${ }^{20}$ yang

${ }^{19}$ Ismail Nawawi, Ekonomi Islam, hlm. 147-152. 
khusus dimanfaatkan untuk kaum muslimin. Dengan demikian, tanah ini menjadi hak milik umum, dan tidak diperbolehkan baik seluruhnya atau sebagian, menjadi milik khusus.

Dalam negara, Rasulullah Saw dulu pernah disuakakan tanah Naqi' yang digunakan untuk tempat mengumpulkan kuda-kuda kaum muslimin. Umar bin Khathab pernah mensuakakan sebidang tanah di Rubdzah. Kaum muslimin yang fakir-fakir dapat menggunakan rumputnya untuk mengembalakan binatang ternak mereka. Tanah ini terlarang untuk orang-orang kaya.

Persuakaan Rasulullah Saw dan Umar r.a. merupakan pengakuan adanya hak milik orang banyak. Sebab dengan adanya hak ini tanah tersebut menjadi milik jamaah kaum muslimin utnuk merealisasikan kemanfaatan umum, yakni dengan membuatnya sebagai tempat menggembalakan kuda-kuda dan unta-unta mereka.

b) Tanah-tanah Ladang Terbuka

Kepemilikan atas tanah ladang terbuka karena ditaklukkan secara kekerasan ada dua pilihan (pertimbangan demi kemaslahatan). Satu dapat dikategorikan ghonimah yakni

20 Salah satu dari kewajiban negara ialah melindungi hak-hak perorangan manusia menurut syariat dan menjamin agar hak-hak itu memenuhi kewajiban-kewajiban mereka terhadap masyarakat sebagaimana ditetapkan oleh hukum. Beginilah Islam mengadakan keseimbangan antara individualisme dan kolektivisme. Abu A'la Al-Maudūdī, Islamic Way of Life, diterjemahkan oleh Osman Raliby dengan judul Pokok-pokok pandangan Hidup Muslim, (Bandung : PT. Al-Ma’arif), hlm. 86-89 
dibagikan kepada para tentara yang ikut perang (yang mendukung pendapat ini mazhab Syafi'ii) dan bisa juga pemerintah menahan tanah tersebut yang kemudian menjadi milik umum dan yang menggunakan dikenakan pajak negara (yang mendukung pendapat ini Mazhab Maliki). Adapun yang mempertimbangkan keduanya diantaranya mazhab Imam Ahmad dan Abu Hanifah. ${ }^{21}$

Dalam surat an-Nisa: 59 dijelaskan yang artinya:

"Hai orang-orang yang beriman, taatilah Allah dan taatilah Rasul-Nya dan ulil amri (pemerintah) di antara kamu..."

Dari arti ayat al-Qur'an di atas mengindikasikan dibolehkannya intervensi pemerintah terhadap suatu kepemilikan. Pemerintah boleh saja menentukan hak milik orang banyak dan membatasi penggunaannya apabila diperlukan oleh kemaslahatan umum. Hal seperti itu perlu dilakukan Rasulullah Saw ketika beliau mempertahankan satu penjuru dari padang rumput yang dibolehkan untuk umum di daerah Naqi. Beliau mengkhususkan tempat itu untuk kuda-kuda dan unta-unta tentara. Ringkasnya sesungguhnya hak milik umum, seperti halnya hak milik khusus, masih terikat dan tidak mutlak.

c. Kepemilikan dan Sebab-sebabnya

1) Al-Ihraz (penguasaan atas harta bebas)

Yaitu dapat dimiliki melalui penguasaan terhadap harta yang belum dimiliki pihak lain.

${ }^{21}$ Ismail Nawawi, Ekonomi Islam, hlm. 153-157. 
Harta tak bertuan (al-mubahat) adalah harta benda yang tidak termasuk dalam milik yang dilindungi dan tidak ada larangan hukum (mani' al-syar') untuk memilikinya. ${ }^{22}$

Contohnya, rerumputan, ikan sungai/ikan lautan dan lain sebagainya. Menurut Wahbah alZuhaily menyatakan setidaknya ada empat cara pengauasaan harta bebas: (a) Membuka lahan baru (ibya' al-mawat), (b) berburu hewan (untuk dimiliki/dikonsumsi), (c) mengumpulkan kayu dan rumut di rimba belukar, dan (d) menggali tambang yang tersimpan diperut bumi. ${ }^{23}$

2) Al-Tawallud (Pengembangbiakan)

Harta atau barang yang dimiliki melalui pembiakan dari harta yang dimilki sebelumnya. Seperti anak kambing dari kambing yang dipelihara, pepohonan dari biji pohon induk yang semula dimiliki dikebun miliknya. Menurut Wahbah al-Zuhaily dalam karyanya inna malikal asli buwa malikul fara, artinya sesungguhnya pemilik utama (induk) adalah pemilik cabangnya.

Segala yang dihasilkan dari sesuatu yang lainnya disebut tawallud. Kaidah yang dijelaskan Wahbah Zuhaily di atas bisa juga diartikan setiap peranakan atau segala suatu yang tumbuh dari harta milik adalah milik pemiliknya. Namun prinsip tawallud hanya berlaku pada harta benda yang bersifat produktif. Berbentuk binatang dan

${ }^{22}$ Musthafa Ahmad al-Zarqa', al-Madkhal al-Fiqh al-'Amm, (Beirut: Daral Fikr, 1968), Jlid I, hlm, 244.

${ }^{23}$ Wahbah al-Zuhaily, al-FIgh al-Islami wa Adillatubu, (Beirut Dar alFikr, 1989), juz. 1, hlm. 70. 
tumbuhan. Adapun yang tidak produktif seperti properti maupun uang tidak terkategori tawallud.

3) Al-Khalafiyah (Penggantian)

Al-Khalafiyah diartikan penggantian seseorang atau sesuatu yang baru menempati posisi pemilikan yang lama. Pertama, harta atau barang diperoleh melalui pewarisan, yaitu harta atau barang yang dapat menjadi milik karena karena mendapatkan bagian dari harta pusaka yang ditinggalkan oleh ahli waris, atau mendapat wasiat untuk memiliki harta dari pemberi wasiat.

Kedua, penggantian benda atas benda yang lainnya, semisal (tadhmin/pertanggungan) ketika seseorang merusak atau menghilangkan harta benda orang lain, atau (ta'widh/ pengganti kerugian) ketika seseorang mengenakan atau menyebabkan penganiayaan terhadap pihak lain. Dengan kedua konsep ini (tadhmin dan ta'widh) ${ }^{24}$ maka diberlakukan peralihan hak milik dari pemilik semula kepada pemilik baru.

4) Al-'Aqd/Akad (Didahului akad)

Harta atau barang yang dimiliki dengan melaksanakan akad, yaitu barang-barang atau harta yang kepemilikannya harus didahului oleh adanya akad. Seperti harta yang diperoleh melalui transaksi jual beli. Dari segi sebab pemilikan dibedakan antara uqud jabariyah dan tamlik. jabariy. ${ }^{25}$

Uqud jabariyah (akad secara paksa) yang dilakukan oleh kuasa hukum atau pengadilan. Contohnya otoritas pengadilan melakukan paksaan

${ }^{24}$ Wahbah al-Zuhaily, al-FIgh al-Islami wa Adillatuhu, hlm. 251.

${ }^{25}$ Musthafa Ahmad al-Zarqa', al-Madkhal al-Fiqh al-'Amm, hlm. 247. 
kepada seseorang untuk menjual harta demi melunasi hutangnya.

Tamlik jabari (pemilikan secara paksa). Jenis ini kemudian dibagi lagi pertama, pemilikan secara paksa atas harta tidak bergerak (mal'uqar) yang akan dijual. Hak pemilikan yang seperti itu disebut dalam fikih mu'amalah 'syufah. Kedua, pemilikan paksa atas dasar kemaslahatan umum. Seperti ketika memperluas masjid atau jalan maka pemilik lahan untuk merelakan tanahnya diminta (dapat ditebus dengan harga yang pantas).

d. Kepemilikan dan Macam-macamnya

Dalam pemahasan fiqh Muamalah, macam-macam kepemilikan ini dapat bagi menjadi dua kategori, yakni:

1) Milku Tam (kepemilikan sempurna/utuh) yakni kepemilikan suatu benda dan juga manfaat dalam kebendaannya. Pemilikan secara utuh ini dapat diperoleh salah satunya melalui proses jual-beli.

2) Milk Naqishah (Kpemilikan sebagian) seseorang diperbolehkan memiliki salah satu dari benda ataukah manfaatnya saja.

2. Implikasi Konsep Kepemilikan Islam Terhadap Pengembangan Ekonomi

Di sini jelas bahwa, memiliki bisa diartikan dengan menguasai, memiliki suatu benda berarti mempunyai hak mengatur dan memanfaatkan selama tidak terdapat larangan dalam syariah. Dengan kepemilikan, pihak yang tidak memiliki tidak berhak menggunakan suatu benda tanpa izin dari pemiliknya. Keterkaitan antara manusia dan hartanya berbeda dengan keterkaitan manusia dengan kepemilikan. Sebab kepemilikan bukanlah hal yang bersifat materi. Dalam Islam kepemilikan membutuhkan 
legalisasi dari syariah. Menurut syariah, kepemilikan adalah sebentuk ikatan antara individu terkait dengan harta, yang pada tahapan proses kepemilikan disyaratkan berbagai hal yang disebut asal usul kepemilikan (asbab al milkiyyah). Selanjutnya syariah mengharuskan beberapa aturan dalam pengoperasian harta dan dalam mengembangkannya. ${ }^{26}$

Menimbang kepemilikan adalah hal yang lazim bagi manusia, maka Allah memberi kekuasaan kepada manusia untuk memiliki apa saja yang ada di bumi, namun dengan catatan manusia harus selalu sadar akan statusnya yang hanya diberi, maka ia harus tunduk kepada yang memberi. Kepatuhan ini harus terwujud mulai saat manusia melakukan proses kepemilikan, hingga dalam menggunakan hak miliknya. Semua harus sesuai dengan syariah yang merupakan ekspresi kehendak Allah. Maka dari itu Islam mengesahkan kepemilikan yang bermula dari proses yang sah, begitu juga sebaliknya, Islam sangat mengecam praktik investasi yang melanggar aturan, terutama jika dengan akibat merugikan masyarakat. Jika perugian terhadap masyarakat ini terjadi, maka si pemilik berarti tidak menghiraukan masyarakat, yang sebenarnya dalam pandangan Islam mempunyai hak dalam kepemilikan individu. Prinsipnya, Islam tidak mengakui segala kepemilikan yang muncul dari cara yang menyimpang. ${ }^{27}$

Pandangan Islam ini jelas berbeda dengan undangundang kepemilikan yang tunduk pada falsafah dan sosial politik dari ekonomi konvensional. Islam menolak paham

${ }^{26}$ Ibid., hlm. 258.

${ }^{27}$ M. Faruq an Nabahan, Sistem Ekonomi Islam : pilihan setelah kegagalan sistem Kapitalis dan Sosialis, alih bahasa : Muhadi Zainuddin, (UII Press, Yogyakarta, 2000), hlm. 41. 
kapitalis, bahwa kepemilikan individu sangat absolut. Islam juga berbeda dengan paham sosialis bahwa kepemilikan adalah tugas kolektif, di samping itu, Islam juga menentang paham bahwa kepemilikan adalah hak bersama. Islam sangat mengakui dan tidak menentang, bahwa kepentingan umum haruslah dipertimbangkan dan didahulukan daripada kepentingan kelompok kecil, apalagi kepentingan individu. Dengan demikian mempertimbangkan kemaslahat umum adalah suatu hal yang harus diterima dalam rumusan kepemilikan.

Islam menolak paham bahwa kepemilikan adalah hak milik kolektif, dengan alasan bahwa hal demikian ini bertentangan dengan milik individu, atau perampasan individu dari hak miliknya, yang sekaligus memberi ruang kepada masuknya intervensi pemerintah dalam kewenangan hak milik. Paham ini jelas memposisikan pemerintah di antara pengatur harta, yang karenanya sah merampas dan selanjutnya memberikan kepada siapa saja yang diberi pemerintah atas dalih undang-undang. ${ }^{28}$

Islam tidak menghendaki terjadinya kepincangan antara hak individu pemilik dan hak masyarakat lain, keberhakan pemilik dalam pandangan Islam adalah hal yang baku. Hanya saja pemerintah mempunyai hak intervensi atas nama undang-undang, dan inipun sangat terbatas pada keadaan tertentu yang kaitannya erat dengan target sosial kemasyarakatan yang hendak diwujudkan.

Peran Islam yang demikian dimaksudkan untuk membantu perimbangan antara hak milik dan hak intervensi yang ditakutkan berlebihan dengan dalih demi kesejahteraan umum. Dalam Islam, hak kepemilikan individu menyangkut hak bersama yang harus diperhatikan, tanpa sedikitpun mengurangi hak hak-hak

${ }^{28}$ Ibid., hlm. 45. 
pribadi pemilik. Islam bertujuan menciptakan masyarakat yang adil dan makmur nan sejahtera, tanpa mengurangi hak milik individu. ${ }^{29}$ Menciptakan masyarakat yang adil dan sejahtera tidak mungkin dibangun tanpa melindungi hak milik individu anggotanya, maka melindungi hak milik individu anggota masyarakat adalah perangkat utama dalam usaha mewujudakan masyarakat yang adil dan makmur. ${ }^{30}$

Dari uraian di atas, dapat disimpulkan bahwa prinsip pemilikan dalam Islam sebagai berikut: ${ }^{31}$

a. Allah Swt adalah penguasa tertinggi, sekaligus pemilik absolut seluruh alam semesta.

b. Manusia hanyalah khalifah Allah Swt di muka bumi bukan pemilik sebenarnya.

c. Semua yang dimiliki didapatkan manusia atas rahmat Allah, oleh karena itu manusia yang kurang beruntung mempuanyai hak atas sebagian kekayaan yang dimiliki saudaranya

d. Kekayaan harus diputar dan tidak boleh ditimbun

e. Eksploitasi ekonomi dalam segala bentuknya, termasuk riba harus dihilangkan

f. Menerapkan sistem warisan sebagai media redistribusi kekayaan yang dapat mengilminasi konflik individu

g. Menetapkan berbagai bentuk sedekah, baik yang bersifat wajib (zakat) maupun yang sukarela, terhadap individu yang memiliki harta kekayaan

${ }^{29}$ Ibid., hlm. 46.

${ }^{30} \mathrm{Baca}$, 'Abd Al-Rahman bin 'Abd Al-Khaliq, Al-Wishoya Al-'Ashr lil 'Amilin bi Al-Da'wah ilallah Subhanabu wa Ta'ala. (Kuwait: Jam'iyah Ihya Turats Al-Islami, Cet. I 1408H/1988H) hlm 69-85.

31 Ismail Nawawi, Ekonomi Islam, Perspektif Teori, Sistem, dan Aspek Hukum (Surabaya: Cv. Putra Media Nusantara, 2008), hlm. 144-147. 
yang banyak, untuk membantu para anggota masyarakat yang tidak mampu.

Agar lebih memudahkan memahami prinsip-prinsip ekonomi di atas ada baiknya kita melihat pendapat Dr. Muhtadi $^{32}$ yang kemudian beliau mengasumsikan setidaknya ada empat tujuan dan nilai-nilai ekonomi Islam yaitu:

a. Kesejahteraan ekonomi dalam kerangka normanorma moral Islam,

b. Persaudaraan dan keadilan universal,

c. Distribusi pendapatan yang adil, dan

d. Kebebasan individu dalam konteks kesejahteraan sosial.

Keempat tujuan dan nilai-nilai tersebut belumlah mencakup semua tujuan dan nilai-nilai ekonomi Islam, tetapi telah cukup memberikan kerangka yang memadai untuk membahas dan menyusun sistem ekonomi menurut Al-Qur'an dan menjelaskan ciri-ciri ekonomi tersebut, yang membedakan dari kedua sistem ekonomi yang menguasai sebagian besar dunia, kapitalisme, dan komunisme.

Namun, betapapun uapaya yang dilakukan oleh manusia dalam mewujudkan prinsip dan tujuan ekonomi tersebut akan bertepuk sebelah tangan sebab perbedaan dan perselisihan antar individu dan masyarakat sering tidak terelakkan. Muhammad Baqir As-Sadr ahli ekonomi Islam, ${ }^{33}$ menurut beliau betapa penting peranan negara ${ }^{34}$ sehingga sehingga beliau memfatwakan kepemilikan

32 A. Muhtadi Ridwan, Al-Qur'an dan Sistem Perekonomian, (Malang: UIN-Maliki Press, 2011), hlm. 87.

33 Mohamed Aslam Haneef, Pemikiran Ekonomi Islam Kontemporer, (Jakarta: PT Rajagrafindo Persada, 2010), cet I, hlm. 139-140.

34 Baca, Robert E. Baldwin, Pembangunan dan Pertumbuban Ekonomi di Negara-negara Berkembang, (Jakarta: PT Bina Aksara, 1986)terj, hlm. 112-125. 
negara mendominasi sistem ekonomi di atas kepemilikan swasta/individu dan publik. Negara yang diwakili oleh wali-e amr memiliki tanggung jawab yang lebih besar untuk menegakkan keadilan dan merealisasikan prinsip-prinsip ekonomi Islam di atas. Hal itu dapat dicapai melalui berbagai fungsi:

a. Distribusi sumber daya alam kepada para individu didasarkan pada kemauan dan kapasitas kerja mereka.

b. Implementasi aturan agama dan hukum terhadap penggunaan sumber.

c. Menjamin keseimbangan sosial.

Fungsi negara yang ketiga itu amat penting karena adanya konflik yang mungkin muncul karena adanya perbedaan kapasitas yang sifat alamiah antarindividu (intelektual maupun fisik). Oleh karena adanya perbedaan tersebut, maka pendapatan akan berbeda pula dan hal ini dapat mengarah pada terbentuknya 'kelas ekonomi'. Negara lebih diharapkan untuk dapat memberikan jaminan terciptanya standard of living yang seimbang bagi semua orang daripada distribusi pendapatan yang merata. Dalam hubungan ini, negara diamanahi untuk mewujudkan jaminan sosial bagi semua orang.

Menurut Sadr, hal ini dapat dicapai dengan mepromosikan persaudaraan (melalui pendidikan) di antara anggota masyarakat dan dengan kebijakan pengeluaran publik, misalnya melalui investasi di sektor publik tertentu yang diarahkanpada pemberian bantukan kepada kaum miskin, serta melalui regulasi kegiatan ekonomi untuk menjamin tegaknya kejujuran dan praktikpraktik yang bebas dari eksploitasi.

Pentingnya menjamin keseimbangan sosial dan keamanan bagi semua orang didasarkan pada prinsip 
bahwa semua sumber daya alam dan hasil-hasilnya harus dinikmati oleh siapa saja. Negara, karena telah mendapat amanah berupa kepemilikan, menjadi terikat pada tugas penjaminan itu dengan cara menolong mereka yang tidak dapat menolong diri mereka sendiri.

Last but certainly not least, negara, ${ }^{35}$ atau lebih tepatnya wali-e amr, mendapat amanah pula untuk menciptakan dinamisme dalam penafsiran teks sesuai dengan situasi kontemporer. Oleh karena hal itu adalah tugas para mujtabidun, berarti bahwa Sadr memandang mujtabidun sebagai negara, yakni negara yang dijalankan oleh para ahli fiqih atau negara yang memiliki semacam dewan penasihat yang terdiri dari para tetua di masyarakat. Demikianlah implikasi konsep kepemilikan Islam terhadap perkembangan ekonomi (Islam).

3. Implikasi Konsep Kepemilikan Islam dalam Pendidikan Agama Islam (PAI)

Dalam pengantarnya, Deputi Gubernur BI menyatakan dewasa ini sistem ekonomi Islam $^{36}$ kembali dilirik, dipelajari, serta diadopsi secara parsial maupun utuh sebagai sistem ekonomi alternatif. ${ }^{37}$

Pendapat di atas dirasa tidak berlebihan mengingat bahwa berabad-abad ekonomi dunia dengan konsep kapitalismenya secara tak langsung menerapkan hukum rimba. Yang kuat atau yang menguasai kapital yang mampu bertahan hidup. Maka dari itu, peran negara dengan pemerintahnya sebagaiman yang digagas oleh Sard di atas hendaknya dipertimbangkan, yaitu

${ }^{35}$ Baca, kebijakan negara dan perilaku birokrasi. J. Panglaykim, Prinsipprinsip Kemajuan Ekonomi, (Jakarta: Buku Kompas, 2011), hlm. 3-187.

36 HM. Dumairi Nor, dkk, Ekonomi Syariah Versi Salaf, (Pasuruan: Pustaka Sidogiri, 2008), hlm. iv.

${ }^{37}$ Baca, Mustafa Edwin Nasution, et al, Pengenalan Eksklusif: Ekonomi Islam, (Jakarta: Kencana, 2007), hlm. 11-32. 
"mepromosikan persaudaraan (melalui pendidikan) dalam masyarakat dan dengan kebijakan pengeluaran publik".

a. Pentingnya Pembelajaran Fikih Muamalah Dalam PAI
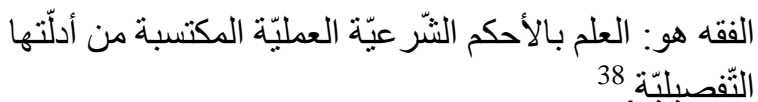

Kurang lebih artinya, fikih adalah ilmu tentang bukumbukum syariat yang didapatkan dengan cara ijtibad pada ayat-ayat al-Qur'an dan Hadits.

Menjadi penting mempelajari Fikih Muamalah karena ia merupakan kumpulan hukum-hukum mengenai hubungan, interaksi, komunikasi sosial atau ibadah horizontal. Melihat pentingnya pembelajaran Fiqh Muamalah dalam praktik Pendidikan Agama Islam (PAI) di tingkat sekolah maka penting merumuskan ulang sejak kapan peserta didik kita mulai mempelajari fikih muamalah tersebut? Pentingnya berpikir dan bertindak ekonom sejatinya telah diteladani oleh Muhammad Saw. Sedari kecil beliau telah nyata menerapkan praktik ekonom, terlepas dari situasi kehidupan beliau. Tetapi kita memandang betapa urgen penanaman jiwa entrepreneur pada anak. Namun, ternyata pendidikan agama Islam kita ternyata lebih sibuk kepada pembibitan pemahaman fikih yang normatif-tekstual.

Kalau di sekolah-sekolah Indonesia, pembelajaran PAI dalam aspek fikih muamalah terutama konsep kepemilikan mulai diterapkan pada jenjang sekolah menengah atas (SMA/MA) kelas 1 (biasa disebut kelas 10) pada semester dua. Dengan muatan materi,

38 Wahbah al-Zuhaili, Ushul al-Figh al-Islami, (Beirut: Dar al-Fikr, tt), hlm. 19 . 
kompetensi dasar dan indikator pencapaian peserta didik sebagai berikut.

Muatan Materi "Memahami hukum Islam tentang kepemilikan" 39

1) Kompetensi Dasar (KD):

a) Mengidentifikasi aturan Islam tentang kepemilikan

b) Menjelaskan ketentuan Islam tentang akad

c) Memperagakan aturan Islam tentang kepemilikan

2) Indikator:

a) Mampu menjelaskan pengertian kepemilikan, macam-macam kepemilikan, dan sebab-sebab kepemilikan

b) Mampu menjelaskan tentang pengertian akad dan menunjukkan dasar hukum akad

c) Mampu menyampaikan syarat-syarat akad, rukun-rukun akad, dan macam-macam akad

d) Mempraktekkan aturan kepemilikan dan akad yang sesuai dengan syari'at Islam ${ }^{40}$

Memperhatikan Standar Kompetensi PAI tema "kepemilikan dalam Islam" di atas cukup menjadi payung besar menaungi pemahaman kompetensi apa yang kelak harus dimiliki peserta didik yakni mereka harus mendapat pengetahuan tentang hukum kepemilikan dalam Islam.

Kemudian kompetensi dasar peserta didik tentang kemampuan memahami, menjelaskan dan memperagakan kepemilikan dalam Islam. Kompetensi Dasar (KD), terkesan masih terlalu memberi porsi

39 Lihat silabus Pendidikan Agama Islam (PAI) untuk kelas 1 SMA/MA sederajad semester II.

${ }^{40}$ Ibid. 
lebih pada ranah pengetahuan dan kemampuan psikomotorinya saja.

Selanjutnya diperinci kembali dalam bentuk indikator-indikator ketercapaiannya. Pada tahap ketiga ini seharusnya sudah merangkul ketiga ranah kompetensi peserta didik yaitu ranah afektif, kognitif dan psikomotorik. Sehingga ketercapaian mereka dalam materi ini benar-benar utuh. Konsep kepemilikan Islam tidak hanya diketahuai dan dapat didemonstrasikan di depan kelas namun kesemua itu menjadi kepribadian si peserta didik dalam praktek entrepreneurnya kelak.

b. PAI dengan Materi Fikih Muamalah "Konsep Kepemilikan dalam Islam" Menanggulangi Pengangguran

Dalam pengertiannya yang paling luas pengagguran berarti keadaan tidak memiliki pekerjaan. Namun, bagi para ekonom definisi tersebut tidaklah memadai.

Ada perbedaan besar antara pekerjaan kantor sementara yang semata-mata sedang berada dalam masa menunggu antara pekerjaan lama dan pekerjaan baru untuk beberapa minggu (pengangguran friksional) dengan seorang mekanik pabrik yang keterampilannya tidak lagi dibutuhkan karena industrinya telah memindahkan sebagian besar produksi kel luar negeri. Yang pertama akan segera kembali bekerja dan memerikan kontribusi pada output ekonomi dari sektor swasta; yang kedua mungkin perlu untuk dilatih kembali, sering kali atas biaya negara untuk suatu periode waktu yang signifikan. ${ }^{41}$

41 Edmund Conway, 50 Gagasan Ekonomi yang Perlu Anda Ketahui, (Jakarta: Esensi Erlangga Group, 2009), terj, hlm. 98. 
Dari pernyataan di atas yang perlu digaris bawahi adalah pengertian orang kedua. Ketika kemampuannya tidak lagi dibutuhkan oleh sebuah perusahaan maka ia akan menganggur sampai ia mencari pekerjaan lagi. Fenomena ini, apabila dikaitkan dengan PAI tentu sangat berhubungan. Dimana Pendidikan Agama Islam (PAI) melalui Fikih Muamalahnya.

Fikih Muamalah merupakan lahan produktif yang dapat dikembangkan oleh guru guna menyemai nilainilai karakter berbasis entrepreneur. Adapun nilai-nilai (karakter) enterpreneur yang dapat ditumbuh kembangkan adalah seperti karakter mandiri dan cinta lingkungan.

Dan tidak menutup kemungkinan kemudian guru menambahkan nilai-nilai karakter lainnya semisal karakter kreatif, komuniktif dan lain sebagainya. Namun, pada kesempatan ini penulis berinisiatif untuk memberikan penekanan pada dua karakter tersebut yang menurut penulis sebagai karakter inti yang harus dikembangkan oleh guru dan dimiliki oleh peserta didik, yakni karakter kemandirian dan kecintaan terhadap lingkungan.

Pertama, Karakter mandiri, akan menghasilkan peserta didik yang berpikir dan bertindak kreatif dalam dunia bisnis. Suatu bisnis tidak mesti dibuktikan berupa perusahaan. Namun, selama bisnis itu dapat menghasilkan maka itu dapat dikategorikan bisnis. Dewasa ini, profesi mengajar, memiliki instansi pendidikan merupakan bisnis. Walaupun sebenarnya, mengajar itu adalah ibadah dan dilandasi niat yang tulus mengharap ridho Allah Swt, akan tetapi, di 
samping bernialai ibadah secara duniawi juga menghasilkan. ${ }^{42}$

Kedua, Karakter cinta lingkungan, dengan karakter ini akan menuntut peserta didik kita untuk tidak hanya sukses dalam bisnis individunya namun juga ia akan senantiasa berbagi kesuksesan tersebut dengan orang sekitarnya (masyarakat), ${ }^{43}$ tapi tidak berhenti di situ dalam hal pemanfaatan alam (SDA) tumbuh kesadaran untuk melestarikannya karena ia yakin pemilik segala di bumi dan langit adalah milik Allah Swt maka harus berbagi ke sesama dan menjaga kelestarian alam suatu keharusan.

\section{Kesimpulan}

Sebagai makhluk kita mempunyai hak kepemilikan. Kepemilikan di sini jika sebagai manusia, adalah sebuah sifat manusiawi yang harus dijaga oleh manusia itu sendiri dan bahkan harus dihormati dan dijamin oleh manusia yang lain tentang kepemilikan tersebut dari ancaman siapapun agar tidak terjadi perampasan hak milik. Hak memiliki dapat digambarkan seperti mulai dari hak kepemilikan terhadap dirinya sendiri, harta dan lain sebagainya.

Akan tetapi manusia tidak cukup lengkap hanya memikirkan dirinya sendiri dan terlena dengan apa yang ia miliki saja padahal ia merupakan mahluk sosial. Sebagai individu yang hidup dalam lingkungan sosial atau bermasyarakat, maka si individu mau tidak mau

42 Jadilah insan rabaniyyah yang saling mencukupi antara kebutuhan jasmani dan ruhani, dua hal yang saling melengkapi. Abu A'la AlMaudūdī, Narriyyah Al-Islam Al-Siyasiyyab; Shaut Al-Haq Katīb Islāmi Syahri, (Mesir: Al-Ittihad Al-‘̄am li Thulāb Jumhuriyyah Misr, 1876), hlm. 28.

43 Jelaslah dengan demikian bahwa tujuan kehidupan (ghäyah Al-Hayät) setiap individu dalam Islam adalah merupakan tujuan bermasyarakat. Rasāil AlMarkaz Al-Islami , Al-Rubäniyyah Al-Ijtimä'iyyah fi Al-Islam, (Suriah: Al-Markaz Al-Islami, 1385H/1965M), hlm. 50-51. 
hendaknya menyadari kewajibannya untuk memenuhi hak-hak dalam bersosial. Sehingga dengan kesadaran sebagai anggota dari komunitas sosial sudah barang tentu ia akan memikirkan orang lain dan bertindak untuk membantu orang lain tersebut serta membuat orang lain dapat berbahagia sebagaimana kebahagiaan yang ia miliki bahkan mengupayakan orang lain lebih bahagia dari dirinya.

Namun kepekaan individu terhadap sosial di atas tidak akan dapat terwujud tanpa campur tangan pihak ketiga. Pada taraf ini peran negara/ pemerintah diperlukan untuk ikut memberi kebijakan, mengatur demi terpenuhinya hak dan terealisasinya kewajiban tersebut.

Adapun implikasi konsep kepemilikan di muka bagi ekonomi Islam dan Pendidikan Agama Islam (PAI) di antaranya, terciptanya manusia sebagai kholifah yang terdidik sehingga mampu hidup mandiri dan mensejahterakan keluarganya, serta dalam memberikan bantuan kepada kaum dhu'afa yang bukan kerabatnya berupa sedekah ataupun zakat diniatkan sebagai salah satu usaha demi meningkatkan kesejahteraan sosial. Lebih jauh lagi, kepemilikan sebagai amanah (berperan sebagai wali-e amr) mampu menciptakan keseimbangan sosial.

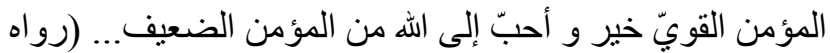

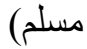

Artinya: seorang mukmin yang kuat baik dan lebih dicintai oleh Allah Swt ketimbang seorang mu'min yang lemah.

Kata “خير" itu maksudnya adalah harta/good sehingga dipahami, seorang mukmin yang kuat hartanya adalah sangat dicintai Allah Swt. Dari hadis sahih ini sebenarnya kita patut menyadari bahwa sebagai mukmin sejati yang mengimani kandungan al-Qur'an dan Hadits 
seyogyanya tidak mudah putus asa akan rotasi kehidupan yang terkadang berada di atas juga di bawah.

Sejatinya Allah Swt sangat mencintai hambahambanya yang kuat, giat bekerja, pantang putus asa serta sebagai mukmin (beriman kepada Allah Swt) sepatutnya memiliki rasa kepedulian yang tinggi terhadap kehidupan sekitarnya dan atau keadaan masyarakatnya yang lemah ekonomi, lemah pendidikan dan lemah kesehatannya.

\section{Referensi}

Abdurrahman al-Jalil, Tamliku al-Amwal wa Tadkhulu alDaulah fi al-Islam, Riyad: Dar al-Ulum, 1988

Ahmad al-Zarqa', Musthafa al-Madkhal al-Figh al-'Amm, Beirut: Dar-al Fikr, 1968 Jlid I

al-Zuhaily, Wahbah al-FIgh al-Islami wa Adillatubu, Beirut Dar al-Fikr, 1989, juz. 1

Ushul al-Figh al-Islami, Beirut: Dar alFikr, tt

Al-Maudūdī, Abu A'la, Islamic Way of Life, diterjemahkan oleh Osman Raliby dengan judul Pokok-pokok pandangan Hidup Muslim, Bandung : PT. Al-Ma'arif

Siyasiyyah; Shaut Al-Haq Katīb Islāmì Syahrì, (Mesir: AlIttihad Al-‘̄m li Thulāb Jumhuriyyah Misr, 1876

Al-Rahman, 'Abd bin 'Abd Al-Khaliq, Al-Wishoya Al-'Ashr lil 'Amilin bi Al-Da'wah ilallah Subhanahu wa Ta'ala. Kuwait: Jam'iyah Ihya Turats Al-Islami, Cet. I $1408 \mathrm{H} / 1988 \mathrm{H}$. 
an Nabahan, M. Faruq, Sistem Ekonomi Islam : pilihan setelah kegagalan sistem Kapitalis dan Sosialis, alih bahasa : Muhadi Zainuddin, UII Press, Yogyakarta, 2000

Aslam Haneef, Mohamed Pemikiran Ekonomi Islam Kontemporer, Jakarta: PT Rajagrafindo Persada, 2010, cet I

Baqir Sadr, Muhammad, Iqtishaduna, Dar al Kitab al Islamiy, ttl

Chapra, M. Umer Masa Depan Ilmu Ekonomi : sebuah tinjauan Islam diterjemahkan oleh : Ikhwan Abidin Basri Jakarta: Gema Insani Press.,2001

Conway, Edmund, 50 Gagasan Ekonomi yang Perlu Anda Ketahui, Jakarta: Esensi Erlangga Group, 2009, terj.

Dagun, Save M. Pengantar Filsafat Ekonomi, Jakarta: PT Rineka Cipta, 1992

Edwin Nasution, Mustafa et al, Pengenalan Eksklusif: Ekonomi Islam, Jakarta: Kencana, 2007

E. Baldwin, Robert Pembangunan dan Pertumbuban Ekonomi di Negara-negara Berkembang, Jakarta: PT Bina Aksara, 1986, terj.

HM. Dumairi Nor, dkk, Ekonomi Syariah Versi Salaf, Pasuruan: Pustaka Sidogiri, 2008 
J. Panglaykim, Prinsip-prinsip Kemajuan Ekonomi, Jakarta: Buku Kompas, 2011

Karl Marx and Frederick Engels, The Communist Manifesto, Harmonsworth : Penguin Books, 1974

Karl Marx and Frederick Engels, The Communist Manifesto, Harmonsworth : Penguin Books, 1974

Mardani, Ayat-ayat dan Hadis Ekonomi Syariah, Jakarta: Rajawali Pers, 2011

M. Hanafi, Syafiq Sistem Ekonomi Islam \& Kapitalisme : relevansi ajaran agama Islam dalam aktivitas ekonomi, Cakrawala, Maret 2007

Munir, Ajaran-ajaran Ekonomi Rasululah Malang: UINMalang Press, 2007

Nawawi, Ismail Ekonomi Islam, Perspektif Teori, Sistem, dan Aspek Hukum Surabaya: Cv. Putra Media Nusantara, 2008

Ekonomi Kelembagaan Syari'ah 'Dalam Pusaran Perekonomian Global Sebuah Tuntutan dan Realitas", Surabaya: Cv. Putra Media Nusantara, 2009

Rasāil Al-Markaz Al-Islami, Al-Rubāniyyah Al-Ijtimä’yyyah fi Al-Islam, (Suriah: Al-Markaz Al-Islami, $1385 \mathrm{H} / 1965 \mathrm{M}$

Ridwan, A. Muhtadi Al-Qur'an dan Sistem Perekonomian, Malang: UIN-Maliki Press, 2011 
Ri'fat Syauqi Nawawi, Misbah, "Perspektif Al-Qur" an tentang Ekonomi”, dalam, Jauhar: Jurnal Pemikiran Islam Kontekstual, Jakarta: PPS UIN Syarif Hidayatullah, 2000, Vol. 1

Sholah, Ibnu, Politik Ekonomi Islam, Bangil: Al-Izzah, 2001, Buku terjemah dari karya Abdurrahman Al-Maliki, as-Syiyasatu al-Iqtishadiyatu al-Mutsla. 